UDC 811.111'373

DOI https://doi.org/10.32841/2409-1154.2021.48-1.10

\author{
Golovnia A. V., \\ Ph. D. in Philology, \\ Assistant Professor at English Philology and Translation Department \\ of the Faculty of Linguistics and Social Communications \\ National Aviation University
}

Shcherbyna A. V.,

Assistant Lecturer at the English Philology and Translation Department

of the Faculty of Linguistics and Social Communications

National Aviation University

\title{
SYNTACTIC MEANS OF SUSPENSE CREATING (BASED THE NOVEL BY NOAH HOWLEY BEFORE THE FALL)
}

\begin{abstract}
Summary. The article is dedicated to the study of syntactic means of creating the effect of tension or suspense in the artistic text of the thriller genre, which is currently increasingly popular among readers. A masterful combination of different stylistic syntactic means, among which there are differenttypes of stylistic repetitions, inversion, asyndetic and polysyndetic types of connection, gradation, parallel constructions, aposiopesis, detached, parenthetical and separated constructions, as well as a number of other means, contribute to the creation of some kind of speed-rhythm balance of the text, which is designed to reflect the course of the reader's thoughts, to penetrate into the depths of the reader's subconsciousness and experiences, to create the necessary level of tension in the text. The research proves the unlimited possibilities of stylistic syntax to create the level of tension needed to keep the readership in suspense, turning a page after page of text to the last one.

Stylistic syntactic means can be used by the author both individually and in combination with each other, depending on the set goal. Thus, the most emotionally coloured are the sentences in which the author combines a number of syntactic tools that are arranged in a sentence according to a certain scheme. Incomplete thoughts and excitement, which are the key elements in creating tension, are conveyed through the sentences at the beginning and end of which the author uses aposiopesis.
\end{abstract}

It is noteworthy that, using a whole arsenal of such artistic syntactic means, the author tries to accentuate them in the text visually. One of the most effective ways to visually accentuate stress is to write new-line sentences, often short, alternating affirmative and interrogative sentences. In this way, the author manages to depict skilfully a number of thoughts and questions that might arise in the reader's mind while reading the text.

Key words: tension, suspense, syntactic stylistic means, fiction, thriller.

One component of the emotional experience that is especially important for any story is tension or suspense that can be defined as the growing interest and excitement experienced by readers in anticipation of a climax or solution in a literary work. It is a feeling of anxious uncertainty about the outcome of events. Writers create tension by asking questions in the minds of their readers. The urgency of the chosen topic is defined by the fact that suspension literature is currently experiencing the peak of its popularity, as evidenced by the significant demand for American, Swedish,
Norwegian, Danish, British thrillers, which are sold out in millions of copies to readers.

Linguistic analysis is one of the most important issues in modern linguistics, at is important to study the constituent units of the literary text, in particular those that create the effect of suspense. Despite the fact that the effect of tension in the literary text has been the subject of a large number of works, the concept of suspense and its various manifestations in the text cannot be called exhaustive, because not enough attention is paid to this term in scientific, practical and theoretical research, by linguists, film and literary critics. A number of scientists and scholars have been investigating the linguistic issue of suspense effect creating in modern fiction, in particular, A.V. Leschenko [1; 2], W. Brewer [3], Y. Iwata [4], L. Klismith [5], M. Lehne and S. Koelsch [6].

Syntax plays a significant role in facilitating imagery in the text, in particular creating suspense. In our particular interest, we have the use of syntactic constructions: various types of repetition, inversions, asyndetic and polysyndetic types of connection, gradation and parallel constructions, etc. The expressive features of the main verb categories are conditioned by the fact that they are directly related to the most important conceptual categories that reflect the reality in our minds and are necessary for its artistic rendering. The possibilities of stylistic syntax allow the author to create the necessary tension in the text, typical of a detective, thriller, psychological novel, etc. - any genre in which you need to keep readers' curiosity and attention in suspense to the last page. Thus, the aim of the article is to investigate syntactic means of suspense creating in the novel by Noah Howley Before the Fall.

Among the main syntactic means used by the author in the novel, the use of the aposiopesis technique predominates. Aposiopesis (break) is a stylistic figure, which is a torn, unfinished sentence. Aposiopesis is used when a character or speaker do not want to continue their thought, or express it to the end, telling all the details. The author deliberately does not complete his thought, he or she gives readers the opportunity to guess, think over what it is, or conveys the tense psychological state of a speaker, for example: "We swam _ I swam _I think it was ten miles. Maybe fifteen" [7].

In this example, in order to depict the tense psychological state of the hero, the author uses the technique of aposiopesis. Accordingly, the reader feels such excitement and understands the level of tension that the hero is experiencing. 
In the novel, this technique is most often used in combination with other techniques. Thus, in the following example, ellipsis is used in combination with the aposiopesis in one phrase:

"Waiting for someone?"

"No. I mean, I think we'll be one more, but =" [7].

Such combination increases the level of tension considerably.

Quite typical of the novel under research is a multiple repetition of a break within one syntactic unit, for example: "Well_I mean = it's hard to remember exactly", Scott tells him. "The plane turned suddenly, pitched, and I_" [7]; "I just__" says Eleanor, "I'm sorry. I can't really make any decisions right now. I just need to = think or take it all in or =" [7]; If David Bateman and his family are really - dead - then why haven't we seen the - and now I'm hearing, and ALC broke this story just hours after the event, that Ben Kipling, the notorious money manager rumored to be on board the flight - that Kipling was about to be indicted by the Treasury Department for trading with the enemy [7]. Thus, in these examples, aposiopesis is used from two to four times, which indicates that the story in the novel has reached a high level of emotional tension, thoughts are not consistent, and the hero is worried about the situation the characters in the novel are involved into.

In most cases, in the novel, aposiopesis is expressed with a dash, for example: "There was banging", he says. "I think. Some kind of _ I want to say concussion" [7].

"And that little boy. Oh my God. So brave. And then = can you believe? = I just saw a thing about the daughter's kidnapping, which = can you imagine?" [7].

Usually, aposiopesis is used either in the middle of the syntactic unit or in the end. In the studied novel there are interesting cases when the syntactic unit begins and ends with aposiopesis, which is a completely unusual technique that maximizes the level of tension in the novel, for example: "--the job, the wife, traffic, bills, whatever =" [7]; "- come on with this fucking thing already =" [7].

Nominative sentences are another stylistic syntactic means of creating tension in the text. The use of nominative sentences and nominative style in general became very popular in the 19th century. Using such sentences, the authors focus on the readers' attention and achieve the desired emotional impact. The use of nominative sentences gives the expression of sharpness and tension, for example: The tornado [7].

The novel is full of simple sentences that are used in different variations. Simple sentences can be used to increase the emotional tension of the narrative or to highlight the character or author attitude to what is happening. After analysing the research material, we found that nominative sentences predominate. For example, a sequence of nominative sentences gives the effect of a dynamic description of events. Such sentences are often used to describe expressively the time of the action, the place of the event, the circumstances of a particular event, the participants in the event, etc., for example: His duffel held clothes, sure, but mostly it was full of slides, pictures of his work. The new work. Hope. His future [7]. In this example, nominative sentences serve to explain the great expectations of the future of the protagonist.

Interestingly, positioning of nominative sentences in the text also affects the expression of the degree of tension. Thus, in a novel, nominative sentences often begin with a paragraph, although they semantically constitute one complete the thought, for example:

A sudden downward pitch.

The panicked stench of burning metal.

Screams [7].
Such arrangement of sentences psychologically tunes the reader to the fact that something terrible is about to happen. Different types of sentences can have such arrangement, and their combination is designed to increase the suspense level, for example:

Crying.

Somewhere a child is crying.

The crying stops [7].

In addition, the repetition of the emotionally coloured word "cry" enhances the psychological effect of stress.

Nominative sentences do not have to be used separately a combination of nominative and simple narrative sentences creates a peculiar rhythm of the narrative, making it slower or faster, depending on what the author intended, for example: Scott thinks back. The takeoff, the offered glass of wine. Images flash through his mind, an astronaut's vertigo, a blare of sounds. Metal shrieking. The disorienting whirl [7]. In the given example, the combination of different types of sentences gives the feeling of retrospective: infused with pieces of memories of the catastrophe, which are extremely painful for the hero.

Nominative sentences are often interrogative in the novel. The sequence of narrative and interrogative nominative sentences is one of the most effective means of creating tension in the text, for example: He thinks about the children. Fuck. There were children. Two, yes? A boy and a girl. How old? The girl was bigger. Ten maybe? But the boy was small, a toddler still [7]. In this example, the reader feels the pulsation of thoughts in the head of the hero, what passions and emotions overwhelm his thoughts and brain.

Another syntactic stylistic device that creates the effect of tension in the novel is interrogative sentences. The use of interrogative sentences usually sets to readers the tasks that are important and need to be solved, for example: What is she looking for, this woman? Is it merely a way out? A clear and sensible path to safety? Or has she lost something? Someone? [7].

Usually, the author states a certain problem and asks problematic questions that can help solve it, for example: A plane has crashed. Was it mechanical failure? Human error? Who can be blamed? Who is liable? [7].

In the novel, interrogative sentences are usually short, which also helps to create tension. Because interrogative sentences are designed to make readers think and satisfy their curiosity about what will happen next, they are typical of this genre, and their number is significant, and they are usually used in the whole series, for example: Should he swim east or west? Back toward the Vineyard or toward the mainland? And yet how will he even know which is which? [7].

Often, interrogative sentences are successively changed by narrative ones, thus creating a certain rhythm in the text and providing answers to questions that interest the reader, for example: But what happens when those details crumble? Hailstones on a tin roof. Fireflies firing at random. What happens when your life can't be translated into a linear narrative? [7]. It is noteworthy that in such a series of sentences the latter is usually interrogative: even if there are answers to previous questions, the reader is left without a basic answer, which forces him or her to remain uncertain and only increase his interest in the plot: Like Scott's dad or Uncle Jake, moustached and potbellied. Like Mr. Branch, his gym teacher with the Afro. Scott couldn't believe it. Was it possible? Could anyone be Superman if they just put their mind to it? If they were willing to do what it took? Whatever it took? [7]. In this example, the last interrogative sentence, which is usually the most emphatic 
and serves as a trigger for readers' tension, the translator highlights in italics, which suddenly increases the level of tension in the text. In this way, the translator seems to be shouting about an unresolved problem that the reader will have to unravel.

Parcelling is another syntactic means used to create tension in the text. Parcelling is the intentional break of a sentence structure into two or more isolated parts separated by a pause and a period. Parcelling is usually characteristic of a spoken language. The main stylistic functions of parcelling are as follows: 1) concretization of some concepts or facts; 2) characteristics of the emotional state of the characters; 3 ) a description of events or images of characters.

In the novel under study, parcelling is used to draw attention to a psychological state, or details of a situation, such as: Handcuffed. Shackled. He was Houdini, except he wasn't trying to escape [7]. In this example, parcelling is used to draw attention to the miserable and hopeless state of the hero, and the reader cannot understand how the character can cope with the challenges of fate.

Parcelling is also used to clarify certain details that may not be immediately clear, such as: They will drown, both of them. They will both be lost to the deep [7]. In the given example by means of parcelling, the author specifies the information which is given in the basic part of the sentence. It is noteworthy that in translation parcelling is not preserved, thereby reducing the sharpness and tension level.

Separated parts of a sentence can be in any position in the text, depending on what you want to draw attention to, for example, in the middle: Day in and day out Eleanor dodged her central defect, locking the door and rolling up the window, eyes doggedly forward, even as its knocks became louder and louder [7].

Parcelling can be at the end of a sentence, for example: Scott measures it instantly at twenty-five feet, a monster bearing down [7]. In the sentence above, the separation of the final part of the sentence also helps to emphasize the final information, and, consequently, encouraging the continuation of the story to understand what will be the development of the plot. In translation, the effect created by parcelling is offset as the translator changes the syntactic structure using a subordinated type of connection.

Parallelism is a stylistic device for creating two or more syntactic structures according to the same syntactic scheme. Syntactic parallelism is multifunctional. He creates rhythm and is characteristic of poetry. It makes speech convincing and is a feature of journalistic and oratorical styles. It emphasizes important information and is widely used in everyday speech. Parallelism can be complete when the structure of the second sentence completely copies the first. Either parallelism can be partial when only the beginning or end of several sentences are structurally similar.

In the studied novel, the use of parallel constructions allows you to create a certain rhythm characteristic of a particular situation, for example: Stroke after stroke, muscle against nature, willpower in defiance of witless primal forces [7].

The parallel constructions used allow the reader to feel all the tension of the situation when the character is trying to fight the element. A similar tension effect is observed in the following example: The crowd was on its feet, urging the swimmer on, stroke by stroke, inch by inch, until Jack LaLanne was walking out of the surf, newsmen wading out to meet him [7].

Parallel constructions in combination with the specific arrangement of sentences in the text contribute to the depiction of tension in the text, for example:
Anything is possible.

Everything is gettable.

You just have to want it badly enough [7].

Each sentence is written on a new line, and with each sentence the level of tension only increases, and the reader feels more confident that everything is possible if desired.

However, on the contrary, parallel constructions might be used in long sentences which express confused ideas and emotions of either the characters or author's narrative. Such sentences make it difficult to follow the thought from the beginning to the end: Scott tells her he remembers his duffel bag by the door, faded green canvas, threadbare in places, remembers pacing, looking for headlights through the window (old milky glass), remembers his watch, the minute hands moving [7].

Detached or parenthetical constructions are also a means of creating tension in the text. Such a construction may be a qualifying, explanatory, or an additional word, phrase, sentence, or other syntactic unit that interrupts a syntactic construction without affecting it in any other way, often with characteristic intonation, and is punctuated by commas, parentheses, or dashes. In the novel, detached or parenthetical constructions are always separated by dashes exceptionally. A detached or parenthetical construction can be both the only one in the text, or a series of them that perform a certain function in the text: And look_I've held my tongue long enough _ but this whole thing smells more than a little fishy to me [7].

Even visually, using a dash instead of a comma acuminates the expression and makes the tension more evident: Apparently, someone broke into their house and took her. She was gone for, like, a week. And now = I mean to survive something like that and then die so horribly = you couldn't make this stuff up" [7].

Detached constructions allow the author to create the highest emotional level in case when they are not single, but used in one sentence several times, for example: First though, came the facts. A private jet - make? model? year built? service history? - had gone missingdeparting airport? destination airport? last radio transmission? radar data? weather conditions? Other planes in the area had been contacted-any sightings? - as had other airports-has the flight been diverted or contacted another tower? But no one had seen or heard from the flight since the precise second that ATC at Teterboro lost track of it [7]. All detached constructions in the example above are short interrogatives, which helps to create a very high level of tension in the text. The author skilfully depicts the thoughts, doubts, questions that dream in the head of the hero of the novel.

Stylistic repetition of language units in a text (separate words, phrases or sentences) is one of the most common and powerful stylistic means. Repetition serves to emphasize certain statements of the speaker, and therefore has significant emotional power, in particular, creating tension in the text. Not only one word can be repeated, but also a phrase and a whole sentence.

The initial elements - anaphora - can be repeated, thus reinforcing the meaning and emotional background of a statement, for example: "Maybe she's okay," Scott whispers. "Maybe your parents have her, and they're floating someplace else. Or maybe they've already been rescued" [7].

The final elements - the epiphora - can be repeated, which allows you to raise the tension of speech at the end, creating a kind of emotional uplift, for example:

Don't give up.

Never give up [7]. 
The effect of tension is enhanced by the location of sentences in the text, where each sentence that contains the epiphora is written from a new line.

In the novel, repetitions are most often used in dialogues. However, they are also characteristic when describing certain situations or thoughts of characters who get into difficult situations, for example: In sleep he is not yet an orphan. In sleep his parents are still alive, his sister. They kiss him on the cheeks and tickle his ribs. In sleep it is last week and he is [7]. Anaphoric repetition "in sleep" helps to portray vividly, and most importantly - to help the reader feel - the difference between imaginary and real stressful situation.

Interestingly, sometimes the stylistic effect of repetition is complemented by the use of other syntactic means: Eleanor would watch and laugh and laugh [7].

Gradation is the arrangement of a sentence or homogeneous parts of a sentence, which provides a gradual increase in the significance, importance or emotional tension in the utterance. The gradation serves to show the development of the situation, for example: But then, like a wound swelling shut, he stopped speaking. And now he is mute [7]. In this example, the gradation depicts the despair and tension of the hero, saying that he eventually became numb.

The following example is interesting from the point of view of pragmatic influence: "And there wasn't any radio contact?" he asks. "No mayday? Nothing" [7]. The sentence ends with an affirmative nominative sentence, stating the fact that the plane disappeared without a trace, without any connection.

Gradation may occur not only within a single sentence, but also within the whole fragment, which consists of a sequence of sentences, for example: But then his father was diagnosed with leukaemia in 2003. He passed away in 2009, and Gus's mother died of an aneurysm a year later. The void their deaths created proved to be beyond the practical comprehension of an engineer [7].

Gradation is usually of three types: logical, emotional, quantitative. In the studied material emotional gradation is used mainly, which clearly reflects the effect of stress.

In addition to all mentioned above stylistic syntactic means of creating tension, there is an antithesis, a stylistic tool that involves the use of a parallel structure, the two parts of which must be semantically opposite to each other, for example: For the second time tonight he has faced certain death and lived [7]. Due to the fact that the lexical units used are semantically opposite, the creation of a tension effect is guaranteed, as confrontation always creates conflict.

In general, the most common are the text fragments, which combine different types of syntactic constructions, and their combination allows you to achieve the maximum effect of tension, for example: But first the cab had to come. First, he had to get to the airfield and get on a private plane - why had he agreed to that? The pressure of it, to travel with strangers - rich strangers - to have to make conversation, discuss his work or, conversely, be ignored, treated like he didn't matter. Which he didn't [7]. In this example, the author skilfully used short sentences, interrogative sentences, which are both detached and convey the internal language of the characters, parcelling.

Thus, in the following example, in order to intensify the tension and draw attention to the situation, the author from the beginning of the fragment uses parcelling, for example:

In his mind, Scott hears a scream. Not of terror, but an involuntary expulsion, a reflexive vocal reaction to something unexpected. It is the sound fear makes when it first appears, the sudden, visceral realization that you are not safe, that this activity you are engaged in is deeply, deeply risky. Your body makes the sound and immediately you break out in a cold sweat. Your sphincter clenches. Your mind, which up until this moment has been moving along at pedestrian speeds, suddenly races forward, running for its life. Fight or flight [7].

In addition to all the above-described methods of creating tension, the author uses capitalization to draw attention to a certain emotionally important point, for example: A banner headline reads, PRIVATE PLANE FEARED LOST [7].

Thus, given the analysed material, it becomes clear that syntactic stylistic means are among the most significant means of creating tension or suspense in the literary text. The use of figures based on the economy (compression) of language means - simple, elliptical and short, fragmentary sentences - contributes to the tension and suspense effect of the story. It is worth noting that nominative and short uncommon sentences usually have a strong position start or end a paragraph. Situational dramatic effect is facilitated by the lack of a formal connection between short sentences, in particular, the use of asyndeton and parcelling.

\section{References:}

1. Лещенко А.В. Нарративная напряжённость художественного текста. Черкассы, 2017. 336 с.

2. Лещенко А.В. Понятие саспенса в контексте современных научных исследований. Science and Education a New Dimension. Philology. 2014. II (6). Is. 29. P. 55-57.

3. Brewer W. The nature of narrative suspense and the problem of rereading. Suspense: Conceptualizations, theoretical analyses and empirical explorations. Mahwah : Lawrence Erlbaum. 1996. P. $107-127$.

4. Iwata Y. Creating suspense and surprise in short literary: a stylistic an narratological approach. Birmingham. 2008. URL: http://www. etheses.bham.ac.uk/284/1/Iwata09PhD.pdf.

5. Klismith L.R. Suspense, Structure, and Point of View: Building Surprise in Fiction . Honors Projects. 2014. Paper 12.

6. Lehne M., Koelsch S. Toward a general psychological model of tension and suspense. Frontiers in Psychology. 2015. P. 61-76.

7. Hawley N. Before the Fall. URL: https://royallib.com/book/Hawley_ Noah/before_the_fall.html.

Головня А., Щербина А. Синтаксичні засоби створення напруги (на матеріалі роману Ноа Гоулі «За мить до падіння»)

Анотація. Статтю присвячено дослідженню синтаксичних засобів створення ефекту напруги, або саспенс, у художньому тексті жанру трилер, який нині популярнй серед читацької аудиторії. Майстерне поєднання різних стилістичних синтаксичних засобів, серед яких переважають різного роду стилістичні повтори, інверсія, сполучниковий та безсполучниковий типи зв'язку, градація, паралельні конструкції, замовчування й обрив думок, вставні та відокремлені конструкції, а також ціла низка інших засобів, сприяє створенню своєрідного темпоритму тексту, що покликаний відобразити перебіг думок читача, проникнути у глибини читацької підсвідомості та переживань, створити необхідний рівень напруги в тексті.

Проведене дослідження доводить безмежні можливості стилістичного синтаксису щодо створення рівня напруги, необхідного для того, щоб утримати увагу читацької аудиторії аж до останньої сторінки тексту. Стилістичні синтаксичні засоби можуть використовуватися автором як поодиноко, так і в поєднанні один з одним, залежно від мети. Найбільш емоційно забарвлені речення, у рамках 
яких автор поєднує низку таких синтаксичних засобів, які розташовані в реченні за визначеною схемою. Незавершеність думок та хвилювання, які є ключовими елементами у створенні напруги, передаються за допомогою речень, на початку і в кінці яких автор використовує апосіопезу.

Прикметно, що в разі використання цілого арсеналу таких художніх синтаксичних засобів автор намагається акцентувати їх у тексті візуально. Серед найефективні- ших способів візуальної акцентуації напруги написання речень із нового рядка, часто коротких стверджувальних та питальних речень, які чергуються. Таким способом автору вдається майстерно відтворити безліч думок та питань, які виникають у голові читача під час читання художнього твору.

Ключові слова: напруга, саспенс, стилістичні синтаксичні засоби, художній текст, трилер. 